\title{
THE EFFECTIVENESS OF HIGH LEVELS OF KNOWLEDGE REGARDING HIV/AIDS IN REDUCING DISCRIMINATORY ATTITUDES AND BEHAVIOUR TOWARDS HIV-INFECTED PEOPLE
}

\author{
M PIRIE \\ WJ COETSEE \\ jc@rau.ac.za \\ Department of Human Resource Management \\ University of Johannesburg
}

\begin{abstract}
The primary objective of this study was to assess whether there is a relationship between increasing levels of knowledge about HIV/AIDS and perceptions of discriminatory attitudes and behaviour towards people with HIV/AIDS. Employees (3662) from a large accounting firm were exposed to a survey and a response rate of $41 \%$ or 1532 was received. The secondary objective of the study was to determine whether there were any statistically significant differences in the mean difference of knowledge scores of groups created in terms of the different biographical variables. ANOVA'S (to determine the significance of differences between the means), t-tests (two groups only) and F-statistics were used for the analysis. Given the large sample size an F-test is not conclusive and the effect of the difference in sample size needs to be taken into account. For this reason it was also necessary to look at the Partial Eta Squared. Results indicate that respondents are generally knowledgeable about the prevention and transmission of HIV/AIDS and that respondents' level of knowledge correlates negatively with discriminatory practices.
\end{abstract}

Key words

Knowledge levels regarding HIV/AIDS, discriminatory attitudes, HIV infected people

HIV/AIDS and its impact on South African Organisations

The HIV/AIDS pandemic threatens the welfare of between 4 to 6 million South Africans (Garbus, 2002), of which an estimated 4, 7 million people are between the age of $15-49$ years (http://hivinsite.ucsf.edu). Furthermore, it is assumed that $25 \%$ of South Africa's economically-active individuals are believed to be HIV positive (Human Science Research Council, 2002; Pangaea Global AIDS Foundations HIV/AIDS Statistics, 2004). This implies that the HIV/AIDS pandemic has dramatically changed the environment in which organisations operate. As indicated in Figure 1, HIV/AIDS undeniably impacts on organisations and workplaces. Barrows, Gallow and Mulleady (1996) argue in this regard that the effect of HIV/AIDS manifests itself in the workplace through increased absenteeism, increased salaries, lower employee morale and higher staff turnover. HIV/AIDS also significantly impacts on organisational goals when investing resources in Black Economic Empowerment and upliftment programmes. Not only has the pandemic a significant impact on an organisation's profits through direct costs and declining economies, but the pandemic deters investment and decreases output which could earn foreign exchange (http://www.corporateleadershipcouncil.com). A study in several Southern and East African countries has estimated that the combined impact of AIDS-related absenteeism, decline in productivity, health care expenditures and recruitment and training expenses could cut profits by at least $6-8 \%$ and that absenteeism can account for as much as $25-54 \%$ of a company's total cost structure (Garbus, 2002).

Despite the mentioned economic challenges, HIV/AIDSrelated stigmatisation, discrimination and denial have characterized the disease for the past twenty years and offered additional challenges for organizations in terms of prevention, care and treatment programmes (Lim \& Loo, 2000). Linking to the previous, HIV/AIDS-related discrimination, stigmatisation and denial have been cited at all stages of the employment relationship (Connors \& Heaven, 1995) and it can be argued that these impact negatively on the psycho-social contract between employer and employee. Regarding the psycho-social contract Veldsman (1996, p. 14) emphasises that the psycho-social contract focuses on the reciprocal expectations of co-responsibility for organizational success and serve as a source of security and legitimacy between the parties, providing stability and predictability to their interactions over time. It can therefore be argued that HIV/AIDS-related discrimination and stigmatization could destabilize the reciprocal expectations in the employee/ employer relationship and could impact negatively on organisational effectiveness. HIV/AIDS discriminatory behaviour manifests itself in the workplace in different ways. Authors such as Aggleton, Whitty, Knight, Prayle, Warwick, and Rivers (1998) state in this regard that stereotyping, exclusion from social events, pre-employment HIV testing, denial of employment to people who test positive or who are suspected to be infected, dismissal, pressure to resign and harassment, employees' refusal to work with infected coworkers or refusal to share communal facilities, exclusion or denial of certain benefits and lack of confidentiality regarding an employee's health status could be regarded as examples of discriminatory practices.

Chandra, Deepthivarma and Manjula (2003) state in this regard that the internalization of these responses on an individual level may result in non-disclosure of HIV/ AIDS status, self-exclusion from information, treatment and care programmes. This presents a major barrier to the effectiveness of educational programmes. Training is generally regarded as an important determinant in creating HIV/AIDS awareness and reducing risk behaviour (Jourdan \& Etkind, 2004). However, training is expensive in terms of production and wages, and much investment in training is wasted because the training is not underpinned by effective models for behavioural change or by a learning environment (Holton \& Baldwin, 2000). Relating to this, the present study seeks to determine if there is a relationship between increasing levels of knowledge about HIV/AIDS and perceptions of discriminatory behaviour toward people with HIV/IADS. 


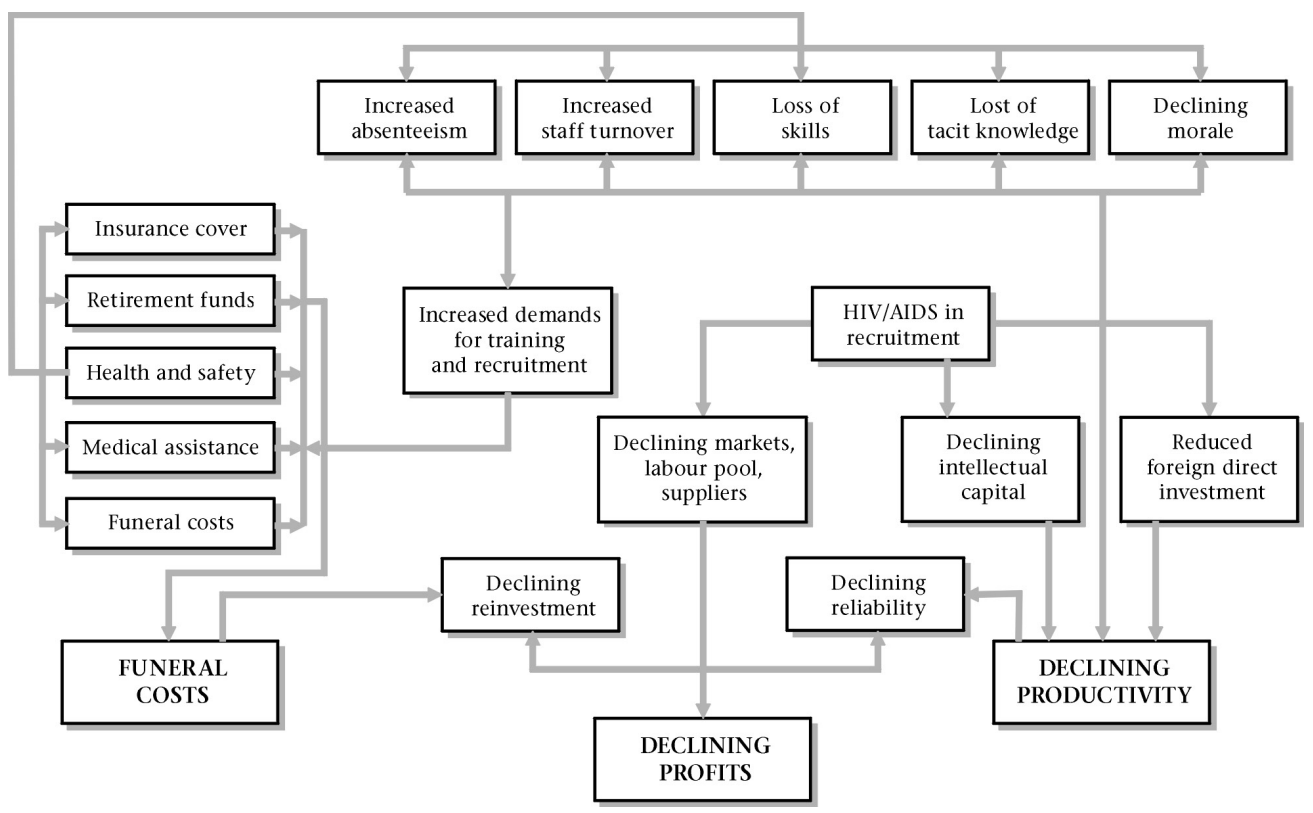

Figure 1: The impact of HIV/AIDS on organisations (UNAIDS, 200)

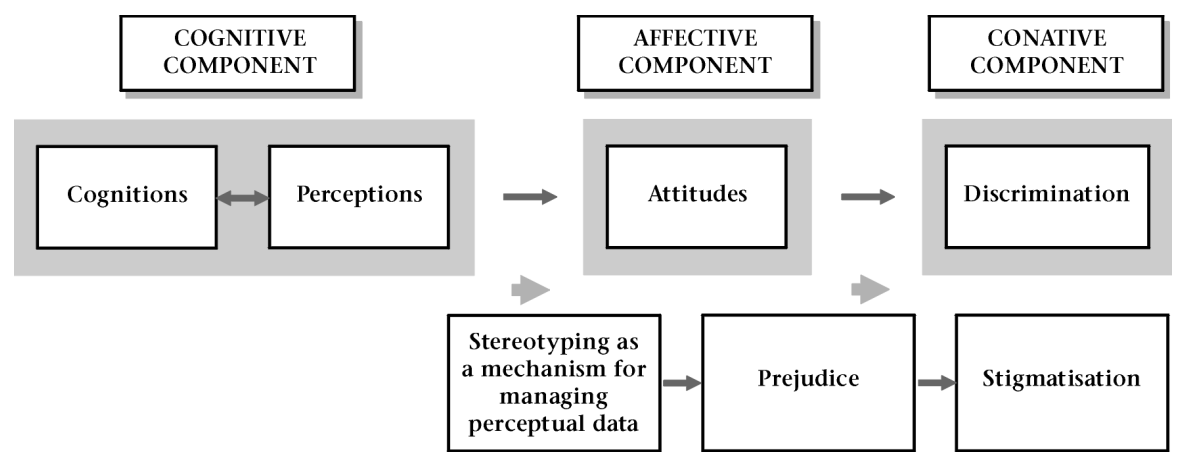

Figure 2: Relationship between cognitive, affective and conative components (Figure taken and adapted from Lewis, 1990)

\section{HIV/AIDS-related Attitudes}

Attitudes, has been variously defined as, stable predispositions (Cox \& Cox, 1991) a general and enduring positive or negative feeling about some person, object, or issue (Arnold, Cooper \& Robertson, 1995; Worchel, Cooper \& Goethals, 1991) a mental state of readiness, learned and organized through experience (Ivancevich \& Matteson, 1996) and consisting of three distinct components i.e.

1. Cognitive component (consists of a person's perceptions, opinions and beliefs);

2. Affective component (consists of the feelings, emotions a person has toward an object); and

3. Behavioural component (refers to the tendency of a person to act in a certain way).

The relationship between the three components is illustrated in Figure 2 and from this it is clear that the components are directly related and dependant upon each other (Lewis, 1990).

The creation of knowledge (i.e. cognitive component) can be understood as the cognitive activity that determines individual understanding and sense making of environmental stimuli. Weick (1995) and Dougherty, Borelli, Munir and O'Sullivan (2000) regard sense making as the process through which people reduce the complexity of their environment and by means of which different information, insight and ideas come together in a meaningful way. This means that information is gathered (through environmental scanning), interpreted and meaning is assigned to the information (Thomas \& Pollock, 1999). Adding to this, Lewis (1990, p. 41) argues that, associated with cognition, is the concept of perception i.e. "...a cognitive process by which an individual gives meaning to the environment and it includes the interpretation of objects, symbols and people in the light of pertinent experiences" (Ivancevich et al., 1996, p. 121; Cook \& Hunsaker, 2001). Dixon (1999) postulates that individuals create meaning structures (intentionally or unintentionally) when they are purposefully trying to understand or learn.

The new meaning structures may corroborate or modify existing meaning structures that the individual has, and when existing meaning structures conflict with new meaning structures, individuals experience an internal sense of uneasiness or dissonance. Closely related to perception is the concept of stereotypes. Stereotyping is the process employed to assist individuals in dealing with information processing demands. This means individuals make assumptions about people solely on the basis of their belonging to a certain race, group or gender (Hellriegel, Jackson \& Slocum, 1999). Attitudes (as illustrated in Figure 2) originate from human cognitions and are closely linked and influenced by perceptions. Prejudice and stigmatisation normally refers to a specific attitude - a combination of hostile feelings, negative emotions and hostile behaviour towards others (Lewis, 1990; Ivancevich et al., 1996). Authors such as Goffman (1963), and 
Parker and Aggleton (2002) describe stigmatisation as a significant discrediting attitude, a process of devaluation or a perceived flaw which allows for its bearer to be treated in a dehumanized way or to reduce the status of the person who possesses it, resulting in a "spoiled identity" (Parker et al. 2002). It is important to note that, apart from beliefs, perceptions and attitudes (which are critical for successful change (i.e. behaviour), there are individual difference variables (e.g. personality traits) that differentiate between individual responses to change (Schalk, Cambell \& Freese, 1998; Weber \& Weber, 2001). The last component illustrated in Figure 2 namely the conative component refers to the likelihood of an individual behaving in a certain way. Given the focus of the study, the term discrimination can be defined as the unfair and unjust treatment of an individual based on his/her real or perceived HIV status, and discrimination is usually seen to follow stigmatisation (UNAIDS, 2003).

Linking to the above, Dixon (1999) argues that individual actions are mediated by meaning structures. This means that stigmatisation and discriminatory behaviour is seen to be a function of the individual's current meaning structures. It can therefore be speculated that those who stigmatise do not understand the condition, lack a relevant frame of reference/meaning structure and that this is supported by inappropriate knowledge of the condition. It is further speculated that other variables that could impact on an individual's ability to construct or reconstruct meaning structures are demographic factors such as age, gender and educational level as well as perceived vulnerability to becoming infected (Norman \& Carr, 2003). According to Chiliaoutakis et al. (1996) the initial characterization of AIDS as being the result of clandestine, immoral and antisocial behaviour as well as the stereotyping of 'high risk' groups on this basis, paves the way to a 'full blown' AIDS social epidemic of stigmatisation and discriminatory practices. It can therefore be argued that HIV/AIDS-related stigmatisation builds upon and reinforces prejudices that already exist and strengthen existing social inequalities. Attribution theory (Ferris, Bhawuk, Fedor \& Judge, 1995; Cook et al. 2001) gives a further explanation of this phenomenon. Martinko (1995) argues in this regard that when an individual's behaviour is observed the observer attempts to determine whether the behaviour was internally caused by the individual or externally by the context or the situation. Three criteria namely distinctiveness (explain whether a person's behaviour fits with other behaviour), consistency (explain the degree of variance in behaviour over time) and consensus (how others behave in similar situations) are used in the attribution process (Cook et al., 2001). This means that society is likely to attribute the cause of HIV/AIDS infections to either internal or external factors and thereby feel that stigmatisation and discriminatory practices are justified. This also illustrates the fact that the behaviour of people is continuously influenced by perceptions and attributions. Figure 3 not only indicates the link between HIV/AIDS and pre-existing sources of stigmatisation and discrimination but also links to factors used in the attribution process.

Furthermore, it can be argued that by stereotyping certain individuals or groups, and through attribution, society can excuse itself from the responsibility of caring for and looking after infected populations. Stereotypes also enable people to justify to themselves why they personally will never be likely to become infected, which leads to a state of denial. Some of the most common forms of denial are to ignore the existence of HIV and AIDS, neglecting to respond to the needs of those infected and failing to recognize the growing epidemic in the belief that HIV/AIDS 'can never happen to us'. Denial fuels AIDS stigmatisation by making those individuals who are infected appear abnormal and exceptional (http://www.avert.org).

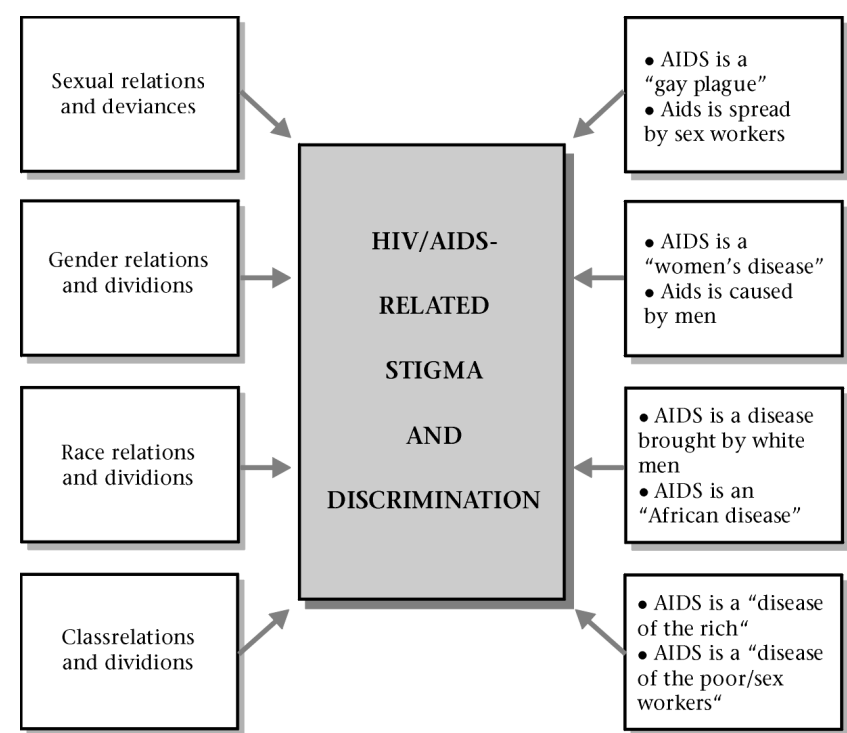

Figure 3: The link between HIV/AIDS and pre-existing sources of stigmatisation and discrimination (Figure taken from Horizons, 2004, p. 3)

HIV/AIDS knowledge and discriminatory behaviour

The majority of HIV/AIDS interventions have the common goal of educating employees regarding HIV/AIDS transmission and prevention so as to reduce the number of new infections, i.e. change individuals' at risk behaviour (Sixsmith, Kelleher \& Crangle, 2000). Organisations therefore need to provide continuous and strategic HIV/AIDS awareness, education and prevention activities integrated into ongoing communication, education and training activities. Despite the importance of continuous HIV/AIDS education and preventative programmes, the impact and effectiveness of these programmes remain questionable (Grunseit \& Aggleton, 1998).

From the literature it is clear that research conducted is inconclusive with regard to whether increases in knowledge alone is sufficient in changing discriminatory attitudes toward people infected with HIV/AIDS. Research conducted by Chiliaoutakis et al. (1996) showed that the higher the level of accurate knowledge about AIDS, the less discrimination and stigmatisation would occur. Unlike the findings of Chiliaoutakis et al. (1996), De Bruyn (1998) found that education will not change everyone's attitudes or prevent stigma and discrimination in every instance. Stigmatized attitudes toward people with HIV/AIDS persist in a minority of the general population and research has demonstrated that negative attitudes toward, for example, homosexuality contribute significantly to such stigmatizing attitudes. Quah (1998) found that the image of HIV/AIDS sufferers is moulded by a person's age and level of information (outcome of formal education and knowledge) on the disease. Ragan and Bowen (2001) found that the provision of information can improve negative attitudes however, the new attitude may be lost without reinforcement for change. Bhate (1999) adds another level of complexity to the debate by stating that when attempting to change attitudes, it is important to know which cognitive styles one is dealing with (adaptors versus innovators) as they follow different patterns in changing attitudes as a result of exposure to negative and positive sources.

Recent international and local research regarding HIV/AIDS knowledge showed that respondents who were younger and had a higher formal education attainment (de Bruyn, 1998; Garbus, 2002; Norman et al., 2003; Steward, 1993) lived in urban rather than rural areas; were employed and had higher household socioeconomic status (Garbus, 2002); had better HIV/AIDS knowledge. No significant gender differential regarding HIV/AIDS knowledge was found (Garbus, 2002). 
With regard to denial and fear, Garbus (2002) found that only 0.5 percent of South Africans believed that there was someone infected with HIV in their families and that up to 92 percent of persons who tested positive for HIV were not able to tell their partners their serostatus. International research shows that stigma, fear of discrimination (http://www.avert.org; Chandra et al., 2003), disgrace to family and self (Lau, Tsui, Li, Chung, Chan $\&$ Molassiotis, 2003), were reported as the main reasons for non disclosure. The majority of subjects (73\%) reported anticipation of negative societal reaction as the main concern following disclosure (Chandra et al., 2003).

The conviction of individuals that they will be discriminated against is confirmed by various studies that show that people would resist working alongside, avoid, or even dismiss an employee if the person was found to be HIV-positive (Barrows, Gallo \& Mulleady, 1996; Lau et al., 2003). Results of a study conducted by Lim and Loo (1999) indicated that respondents view the employing of people with HIV/AIDS as holding adverse consequences for the organisation.

A number of studies have shown a positive correlation between perceived personal risk of contracting the disease and knowledge of the disease. The Kaiser Youth Survey undertaken in 2000 showed that $54 \%$ of respondents indicated that they are afraid they may contract HIV and that $66 \%$ agreed with the statement "I could die of AIDS" (Garbus, 2002). A study in Trinidad of 1 351 adults showed that knowledge was associated with concern about personal risk of HIV (Quah, 1998) and that the image of HIV/AIDS is less important than the joint impact of accepting personal responsibility and the perceived seriousness of the disease (Norman et al., 2003).

The finding is that research is inconclusive and lacking with regard to the link between the extent of HIV/AIDS knowledge, attitude towards infected and affected people and resulting behaviour (discriminating, indifferent or accepting). Although knowledge appears to be a very important variable in reducing stigma and discrimination, it is clearly not the only variable. Existing studies looking into the role that a supportive, protective and caring environment plays in reducing HIV/AIDS discrimination can also be expanded on. To date only a limited amount of research has examined working adults' attitudes towards infected colleagues in the workplace. It would appear that research in South Africa regarding mechanisms involved in the stigmatisation of risk behaviours, the socio-cultural construction of risk, attitudes of discrimination, and attitudes based on fear, have not received much scientific attention at all. The research that has been conducted on the last mentioned issues has also mainly been of international origin. Bearing in mind that cultural differences may influence people's attitudes (Quah, 1998) towards having to work with an HIV-infected colleague, a case can be made that it is worthwhile examining individuals' attitudinal and intended behavioral responses towards infected people in the organisational setting within the South African context. The problematic nature of stigmatisation and discrimination as social processes or phenomena are summarized by Parker et al. (2002, p14):

"Much of what has been written about stigma and discrimination in the context of HIV and AIDS has emphasised the complexity of these phenomena, and has attributed our inability to respond more effectively to both their complex nature and their high degree of diversity in different cultural settings".

\section{Objectives of the study}

The primary objective of the study was to determine if there is a relationship between increasing levels of knowledge about HIV/AIDS and perceptions of discriminatory attitudes and behaviour towards people with HIV/AIDS. The secondary objective of the study was to determine if there are any statistically significant differences in the mean difference scores between levels of knowledge with regard to educational qualifications, sex, age and high-risk behaviour. This comparison would assess whether different comparison groups have different mental models regarding positive HIV/ AIDS employees. The previously mentioned objectives have been implemented by utilizing exploratory means, including a questionnaire that was compiled with the aim of measuring knowledge levels of the respondents regarding HIV/AIDS. The research design is further explained and developed in the next section.

\section{RESEARCH DESIGN}

\section{Research Methodology}

This study is a quantitative study and a cross-sectional survey design was used to describe the information on the population collected. The study is also exploratory and descriptive as well as retrospective in nature (i.e. it was done on retrospective data). Elements of the research design are predetermined and in addition it is ex post facto and attempts to show causes and consequences after they have occurred.

\section{Respondents}

Due to the inherent educational value that knowledge, attitude, practices and behaviour (KAPB) surveys have, all 3662 employees of a large accounting firm situated in nine regions (See Table 1) were exposed to the survey.

TABLE 1

GeOgRAPHIC REGIONS

\begin{tabular}{lcr}
\hline Region of work & Count & $\%$ \\
\hline Eastern Cape & 92 & $6,0 \%$ \\
Free State & 72 & $4,7 \%$ \\
Gauteng & 763 & $49,8 \%$ \\
Kwazulu Natal & 136 & $8,9 \%$ \\
Limpopo & 16 & $1,0 \%$ \\
Mpumalanga & 20 & $1,3 \%$ \\
North West & 36 & $2,4 \%$ \\
Northern Cape & 43 & $2,8 \%$ \\
Western Cape & 353 & $23,1 \%$ \\
Total & 1531 & $100,0 \%$ \\
\hline
\end{tabular}

A response return rate of $41 \%(\mathrm{~N}=1532)$ was achieved. Employees from offices situated in Gauteng, Kwa-Zulu, Free State, Western Cape, Northern Cape, North West, Mpumalanga, Limpopo participated in and responded to the survey. The employment setting was predominantly white collar and participants operated in diverse functional areas e.g. from professional staff such as accountants to support and administrative personnel.

Table 2 gives an indication of the ages of the respondents.

TABLE 2

AgE OF RESPONDENTS

\begin{tabular}{lcr}
\hline Age & Count & $\%$ \\
\hline 19 and younger & 8 & $0,5 \%$ \\
$20-24$ & 287 & $18,7 \%$ \\
$25-29$ & 496 & $32,4 \%$ \\
$30-34$ & 277 & $18,1 \%$ \\
$35-39$ & 150 & $9,8 \%$ \\
$40-44$ & 123 & $8,0 \%$ \\
$45-49$ & 80 & $5,2 \%$ \\
50 and older & 110 & $7,2 \%$ \\
Total & 1531 & $100,0 \%$ \\
\hline
\end{tabular}


Respondents ages ranged from as young as $19(0,5 \%)$ to age 50 and older (7\%) with the majority of employees (32\%) in the 25 - 29 year age category $(\mathrm{N}=496)$. The sample indicated a leaning towards female respondents $(\mathrm{N}=902)$, with male respondents accounting for $41 \%$ of the sample $(\mathrm{N}=627)$. The educational level of the sample varied between high school, college and university, with the majority of respondents (63\%) reporting a university degree $(N=963)$. See Table 3 in this regard.

TABLE 3

Educational LeVels

\begin{tabular}{lcr}
\hline Highest educational level & Count & $\%$ \\
\hline College/Technikon & 267 & $17,4 \%$ \\
High school & 284 & $18,5 \%$ \\
Primary school & 17 & $1,1 \%$ \\
University & 963 & $62,9 \%$ \\
Total & 1531 & $100,0 \%$ \\
\hline
\end{tabular}

More than half of the respondents (52\%) indicated that they were in a relationship with the remaining $48 \%$ indicating that they were single at the time.

\section{Measuring Instrument}

In the research, a questionnaire consisting of 32 items and comprising three sections was utilized. Section A recorded the demographic data of the various respondents. Section B (22 items) measured the level of knowledge of the respondents regarding HIV/AIDS and Section C (10 items) measured discriminatory practices regarding an HIV-positive individual. Various literature sources were used in the compilation of the questionnaire. In this regard the ILO Code of Practice on HIV/AIDS and research done by the World Health Organisation refer. Following the study of different knowledge domains, it appears that information regarding HIV/AIDS is centered around the following themes:

1. How is the virus contracted?

2. What is the cause of HIV/AIDS?

3. Employees concerns, myths and fears;

4. Prevention and control of the spread of the virus;

5. Testing for HIV/AIDS;

6. Discriminatory practices.

The abovementioned themes served as point of departure in formulating the questions. Each of the items in the HIV/AIDS Knowledge Questionnaire is presented in the form of a threepoint scale namely Agree, Uncertain, and Disagree. This format is most appropriate, given the objective of the study, i.e. to assess the level of knowledge of the respondents. For the purpose of this study all questions answered as Uncertain were considered to be incorrect answers, which indicated a lack of knowledge. An example of the item construction is included.

"Do you believe HIV/AIDS can be cured?"

\begin{tabular}{l|l|l} 
Agree & Uncertain & Disagree
\end{tabular}

"Do you believe that you can prevent becoming infected by wearing a condom during intercourse?"

\begin{tabular}{|l|l|l|}
\hline Agree & Uncertain & Disagree \\
\hline
\end{tabular}

\section{Procedure}

A pre-survey distribution, meeting was held with the participating organisations stakeholders. The aim of the workshop was to familiarise stakeholders with the HIV/AIDS Knowledge Questionnaire content and with the procedures of distribution to ensure buy-in into the process, efficient survey delivery and minimizing possible misunderstandings.
Surveys were distributed amongst all of the participating organisations' employees. Although the majority of surveys were distributed electronically a small number of hard copies were distributed to employees who were not able to obtain them or did not have access to the electronic version.

Employees also received an email or letter from the Deputy Chief Executive Officer of the participating organisation that explained the objectives of the survey and encouraged participation. Employees were asked to either return the survey electronically or to place completed questionnaires in the collection boxes provided. Employees were assured that the data would be kept confidential and anonymous.

\section{RESULTS}

The secondary objective of the study was to determine whether there were any statistically significant differences in the mean difference of knowledge scores of groups created in terms of the different biographical variables. ANOVA'S (to determine the significance in difference between the means), t-tests (two groups only) and F-statistics were used for the analysis. Given the large sample size, an F-test is not conclusive and the effect of the difference in sample size needs to be taken into account. For this reason it was also necessary to utilize the Partial Eta Squared.

\section{HIV/AIDS Knowledge Questionnaire}

The items utilized in the questionnaire are indicated in Table 4. Given the purpose of the investigation, namely to determine the relationship between increasing levels of knowledge about HIV/AIDS and perceptions of discriminatory attitudes and behaviour towards people with HIV/AIDS, items were included that are considered by inspection to have face validity.

The pilot questionnaire can therefore serve as point of departure in compiling and refining a subsequent questionnaire. It is apparent from Table 4 that questions $1 ; 6 ; 7 ; 9 ; 11 ; 12 ; 15 ; 16$ possess a relatively low discriminatory value and it is recommended that the items be excluded from any subsequent questionnaire.

TABLE 4

KNOWLEDGE QUESTIONS AND DISCRIMINATORY PRACTICES

\begin{tabular}{|c|c|c|c|c|}
\hline \multicolumn{2}{|l|}{ SECTION B: KNOWLEDGE } & \multirow{2}{*}{$\begin{array}{r}\text { Agree } \\
1480 \\
96,8 \%\end{array}$} & \multirow{2}{*}{$\begin{array}{r}\text { Uncertain } \\
28 \\
1,8 \%\end{array}$} & \multirow{2}{*}{$\begin{array}{c}\text { Disagree } \\
21 \\
1,4 \%\end{array}$} \\
\hline $\begin{array}{l}\text { 1. A blood test can show whether } \\
\text { someone has HIV/AIDS }\end{array}$ & $\begin{array}{l}\text { Count } \\
\%\end{array}$ & & & \\
\hline $\begin{array}{l}\text { 2. It is possible to have a negative } \\
\text { HIV blood test in the first couple } \\
\text { of months after becoming } \\
\text { infected with HIV }\end{array}$ & $\begin{array}{l}\text { Count } \\
\%\end{array}$ & $\begin{array}{r}1251 \\
82,1 \%\end{array}$ & $\begin{array}{r}178 \\
11,7 \%\end{array}$ & $\begin{array}{l}94 \\
6,2 \%\end{array}$ \\
\hline $\begin{array}{l}\text { 3. An HIV-positive mother who is } \\
\text { breast-feeding can pass the HIV } \\
\text { virus on to her baby }\end{array}$ & $\begin{array}{l}\text { Count } \\
\%\end{array}$ & $\begin{array}{r}1127 \\
73,7 \%\end{array}$ & $\begin{array}{r}207 \\
13,5 \%\end{array}$ & $\begin{array}{l}195 \\
12,8 \%\end{array}$ \\
\hline 4. HIV/AIDS can be cured & $\begin{array}{l}\text { Count } \\
\%\end{array}$ & $\begin{array}{r}204 \\
13,3 \%\end{array}$ & $\begin{array}{r}193 \\
12,6 \%\end{array}$ & $\begin{aligned} & 1132 \\
& 74,0 \%\end{aligned}$ \\
\hline $\begin{array}{l}\text { 5. The presence of a sexually } \\
\text { transmitted disease can increase } \\
\text { the risk of HIV transmission }\end{array}$ & $\begin{array}{l}\text { Count } \\
\%\end{array}$ & $\begin{array}{r}1175 \\
76,7 \%\end{array}$ & $\begin{array}{r}192 \\
12,5 \%\end{array}$ & $\begin{array}{l}164 \\
10,7 \%\end{array}$ \\
\hline $\begin{array}{l}\text { 6. A pregnant woman who has } \\
\text { HIV/AIDS can pass the HIV virus } \\
\text { on to her unborn baby }\end{array}$ & $\begin{array}{l}\text { Count } \\
\%\end{array}$ & $\begin{array}{r}1437 \\
93,9 \%\end{array}$ & $\begin{array}{r}42 \\
2,7 \%\end{array}$ & $\begin{array}{l}52 \\
3,4 \%\end{array}$ \\
\hline $\begin{array}{l}\text { 7. TB can be cured if treatment is } \\
\text { given early enough }\end{array}$ & $\begin{array}{l}\text { Count } \\
\%\end{array}$ & $\begin{array}{r}1474 \\
96,3 \%\end{array}$ & $\begin{array}{r}44 \\
2,9 \%\end{array}$ & $\begin{array}{l}12 \\
0,8 \%\end{array}$ \\
\hline $\begin{array}{l}\text { 8. There is a difference between } \\
\text { being HIV-positive and having } \\
\text { AIDS }\end{array}$ & $\begin{array}{l}\text { Count } \\
\%\end{array}$ & $\begin{array}{r}1317 \\
86,1 \%\end{array}$ & $\begin{array}{r}64 \\
4,2 \%\end{array}$ & $\begin{array}{l}149 \\
\quad 9,7 \%\end{array}$ \\
\hline $\begin{array}{l}\text { 9. A person can be HIV-positive for } \\
\text { many years without becoming ill }\end{array}$ & $\begin{array}{l}\text { Count } \\
\%\end{array}$ & $\begin{array}{r}1438 \\
93,9 \%\end{array}$ & $\begin{array}{r}54 \\
3,5 \%\end{array}$ & $\begin{array}{l}40 \\
2,6 \%\end{array}$ \\
\hline $\begin{array}{l}\text { 10. Tuberculosis }(\mathrm{TB}) \text { is often } \\
\text { considered to be an AIDS } \\
\text { related disease }\end{array}$ & $\begin{array}{l}\text { Count } \\
\%\end{array}$ & $\begin{array}{r}692 \\
45,3 \%\end{array}$ & $\begin{array}{r}225 \\
14,7 \%\end{array}$ & $\begin{array}{l}612 \\
40,0 \%\end{array}$ \\
\hline
\end{tabular}


11. You can tell by looking at someone that they are infected

12. You can become infected by touching the body of a person who has HIV/AIDS

13. You can become infected by kissing a person who has HIV/AIDS

14. You can become infected by sharing food or eating utensils with a person who has HIV/AIDS

15. You can become infected by using Syringes/needles previously used by a person who has HIV/AIDS

16. You one can become infected by having unprotected (no condom) sex

17. You can become infected by being bitten by a mosquito that previously bit an HIV-infected person

18. You can become infected by using the same toilet seats as HIV-infected people

19. You can become infected by being in contact with the perspiration (sweat) of a person who has HIV/AIDS

20. You can prevent becoming infected if you wear a condom

21 . There are female condoms that are effective in the prevention of HIV transmission

22. Contraceptive practices such as the pill etc. can also prevent HIVtransmission

\begin{tabular}{|c|c|c|c|}
\hline Count & 65 & 71 & 1393 \\
\hline$\%$ & $4,3 \%$ & $4,6 \%$ & $91,1 \%$ \\
\hline Count & 35 & 20 & 1476 \\
\hline$\%$ & $2,3 \%$ & $1,3 \%$ & $96,4 \%$ \\
\hline Count & 214 & 149 & 1167 \\
\hline$\%$ & $14,0 \%$ & $9,7 \%$ & $76,3 \%$ \\
\hline Count & 88 & 82 & 1361 \\
\hline$\%$ & $5,7 \%$ & $5,4 \%$ & $88,9 \%$ \\
\hline Count & 1507 & 6 & 17 \\
\hline$\%$ & $98,5 \%$ & $0,4 \%$ & $1,1 \%$ \\
\hline Count & 1518 & 2 & 11 \\
\hline$\%$ & $99,2 \%$ & $0,1 \%$ & $0,7 \%$ \\
\hline Count & 222 & 377 & 931 \\
\hline$\%$ & $14,5 \%$ & $24,6 \%$ & $60,8 \%$ \\
\hline Count & 57 & 79 & 1396 \\
\hline$\%$ & $3,7 \%$ & $5,2 \%$ & $91,1 \%$ \\
\hline Count & 51 & 152 & 1327 \\
\hline$\%$ & $3,3 \%$ & $9,9 \%$ & $86,7 \%$ \\
\hline Count & 1264 & 88 & 178 \\
\hline$\%$ & $82,6 \%$ & $5,8 \%$ & $11,6 \%$ \\
\hline Count & 574 & 551 & 405 \\
\hline$\%$ & $37,5 \%$ & $36,0 \%$ & $26,5 \%$ \\
\hline Count & 30 & 56 & 1444 \\
\hline$\%$ & $2,0 \%$ & $3,7 \%$ & $94,4 \%$ \\
\hline
\end{tabular}

SECTION C: DISCRIMINATORY PRACTICES Disagree Uncertain Agree

\begin{tabular}{llllll}
\hline 1. If you were infected, do you & Count & 210 & 639 & 673
\end{tabular} believe that your colleagues $\quad \% \quad 13,8 \% \quad 42,0 \% \quad 44,2 \%$ would avoid you if they found out that you had HIV/AIDS?

2. Would you feel comfortable $\quad$ Count $\quad 314 \quad 396 \quad 818$ working with a colleague if you $\quad \begin{array}{lllr}\% & 20,5 \% & 25,9 \% & 53,5 \%\end{array}$ knew that he/she was HIVpositive?

3. Would you feel comfortable sharing toilets with an HIV infected colleague?

4. Would you feel comfortable sharing equipment/tools with an HIV-infected colleague? $\begin{array}{llrrr}\text { 5. Would you feel comfortable } & \text { Count } & 417 & 297 & 814 \\ \text { sharing cutlery/crockery with an } & \% & 27,3 \% & 19,4 \% & 53,3 \%\end{array}$ HIV-infected colleague?

6. Do you believe that CO. X would Count $\quad 986 \quad 426 \quad 115$ attempt to dismiss you if they $\quad \% \quad 64,6 \% \quad 27,9 \% \quad 7,5 \%$ found out that you were HIV positive?

7. Should you become infected with Count $598 \quad 494 \quad 433$ $\begin{array}{lllrr}\text { HIV /AIDS would you tell your } & \% & 39,2 \% & 32,4 \% & 28,4 \%\end{array}$ manager/supervisor?

8. Should you become infected with Count $\quad 576 \quad 474 \quad 476$ HIV/AIDS would you tell your $\quad \% \quad 37,7 \% \quad 31,1 \% \quad 31,2 \%$ HR manager?

The descriptive statistics for different educational levels are depicted in Table 5. From Table 1 it is clear that the majority of respondents are University graduates. Respectively, 284 respondents (19\%) are in possession of a High School diploma and 267 respondents $(18 \%)$ are in possession of a college or technicon qualification.

Given the sample size, statistically significant differences (Table 6) were found in the mean scores between levels of education and knowledge levels of the respondents.(F 2; $1511=34,776$, p <
0,0005). However, based on the effect size, Partial ETA Squared (Table 2), the effect of level of education on knowledge is relatively small as $\mathrm{ETA}=0,21<0,3$

TABLE 5

DESCRIPTIVE STATISTICS ACCORDING TO LEVELS OF EDUCATION

\begin{tabular}{|c|c|c|c|c|c|c|c|c|}
\hline & \multirow[b]{2}{*}{$\mathbf{N}$} & \multirow[b]{2}{*}{ Mean } & \multirow[b]{2}{*}{$\begin{array}{c}\text { Std. } \\
\text { Deviation }\end{array}$} & \multicolumn{3}{|c|}{$\begin{array}{l}95 \% \text { Confidence } \\
\text { Interval for Mean }\end{array}$} & \multirow[b]{2}{*}{$\begin{array}{l}\text { Mini- } \\
\text { mum }\end{array}$} & \multirow[b]{2}{*}{$\begin{array}{l}\text { Maxi- } \\
\text { mum }\end{array}$} \\
\hline & & & & $\begin{array}{l}\text { Std. } \\
\text { Error }\end{array}$ & $\begin{array}{l}\text { Lower } \\
\text { Bound }\end{array}$ & $\begin{array}{l}\text { Upper } \\
\text { Bound }\end{array}$ & & \\
\hline $\begin{array}{l}\text { College/ } \\
\text { Technico }\end{array}$ & 267 & 82,1927 & 10,82341 & 0,66238 & 80,8885 & 83,4969 & & \\
\hline $\begin{array}{l}\text { High } \\
\text { school }\end{array}$ & 284 & 78,5851 & 13,19370 & 0,78290 & 77,0441 & 80,1262 & 36,36 & 100,00 \\
\hline $\begin{array}{l}\text { Univer- } \\
\text { sity }\end{array}$ & 963 & 84,4898 & 9,67387 & 0,31174 & 83,8780 & 85,1015 & 31,82 & 100,00 \\
\hline Total & 1514 & 82,9771 & 10,85558 & 0,27899 & 82,4298 & 83,5243 & 31,82 & 100,00 \\
\hline
\end{tabular}

TABLE 6

ANOVA: COMPARISONS OF LEVELS OF EDUCATION IN RESPECT OF LEVEL OF KNOWLEDGE

\begin{tabular}{lrrrrrr}
\hline & $\begin{array}{c}\text { Sum of } \\
\text { Squares }\end{array}$ & df & $\begin{array}{c}\text { Mean } \\
\text { Square }\end{array}$ & F & Sig. & ETA \\
\hline Between Groups & 7845,893 & 2 & 3922,947 & 34,776 & 0,000 & 0,210 \\
Within Groups & 170451,376 & 1511 & 112,807 & & & \\
Total & 178297,270 & 1513 & & & & \\
\hline
\end{tabular}

ETA

$0,1-0,3$ (Small effect)

$0,4-0,5$ (Moderate effect)

$>0,5$ (Large effect)

TABLE 7

LEVENE'S TEST OF EQUALITY OF ERROR VARIANCES

\begin{tabular}{cccc}
\hline Levene Statistic & df 1 & df 2 & Sig. \\
\hline 19,994 & 2 & 1511 & 0,000
\end{tabular}

The results of the Levene's test for equality of error variances are depicted in Table 3 . As the null hypotheses of equal variances is rejected (see Table 7), Dunnett T3 post hoc tests are used to ascertain which of the educational groups differ significantly.

TABLE 8

Post Hoc Tests: MulTiPle Comparisons BeTWEeN LEVELS OF EDUCATION

\begin{tabular}{|c|c|c|c|c|c|c|c|}
\hline & & & & $95 \%$ & Confide & nce Inte & rval \\
\hline & $\begin{array}{l}\text { (I) } \\
\text { (Recoded) } \\
\text { Highest } \\
\text { educa- } \\
\text { tion level }\end{array}$ & $\begin{array}{l}(\mathrm{J}) \\
\text { (Recoded) } \\
\text { Highest } \\
\text { educa- } \\
\text { tion level }\end{array}$ & $\begin{array}{l}\text { Mean } \\
\text { Dif- } \\
\text { ference } \\
(I-J)\end{array}$ & $\begin{array}{l}\text { Std. } \\
\text { Error }\end{array}$ & Sig. & $\begin{array}{l}\text { Lower } \\
\text { Bound }\end{array}$ & $\begin{array}{l}\text { Upper } \\
\text { Bound }\end{array}$ \\
\hline \multirow[t]{6}{*}{$\begin{array}{l}\text { Dunnett } \\
\text { T3 }\end{array}$} & $\begin{array}{l}\text { College/ } \\
\text { Techni- } \\
\text { kon }\end{array}$ & $\begin{array}{l}\text { High } \\
\text { school }\end{array}$ & $3,6076\left(^{*}\right)$ & 1,02552 & 0,001 & 1,1515 & 6,0636 \\
\hline & & $\begin{array}{l}\text { Uni- } \\
\text { versity }\end{array}$ & $-2,2970\left(^{*}\right)$ & 0,73207 & 0,005 & $-4,0523$ & $-0,5418$ \\
\hline & $\begin{array}{l}\text { High } \\
\text { school }\end{array}$ & $\begin{array}{l}\text { College/ } \\
\text { Techniko }\end{array}$ & $\begin{array}{l}-3,6076\left(^{*}\right) \\
n\end{array}$ & 1,02552 & 0,001 & $-6,0636$ & $-1,1515$ \\
\hline & & $\begin{array}{l}\text { Uni- } \\
\text { versity }\end{array}$ & $-5,9046\left({ }^{*}\right)$ & 0,84268 & 0,000 & $-7,9254$ & $-3,8838$ \\
\hline & $\begin{array}{l}\text { Uni- } \\
\text { versity }\end{array}$ & $\begin{array}{l}\text { College/ } \\
\text { Techniko }\end{array}$ & $2,2970\left(^{*}\right)$ & 0,73207 & 0,005 & 0,5418 & 4,0523 \\
\hline & & $\begin{array}{l}\text { High } \\
\text { school }\end{array}$ & $5,9046\left(^{*}\right)$ & 0,84268 & 0,000 & 3,8838 & 7,9254 \\
\hline
\end{tabular}

*The mean difference is significant at the 0,05 level. 
The results of the Dunnett T3 post hoc tests for the different educational levels are depicted in Table 8 . From Table 8 it is clear that there are significant differences in mean between the groups: College/Technicon, High School and University graduates. From Table 5 it is clear that respondents who have a University degree have a higher level of knowledge than respondents who have a High School or Technikon qualification.

TABle 9

DESCRIPTIVE STATISTICS ON GENDER GROUPS

\begin{tabular}{lccccc}
\hline & Gender & N & Mean & $\begin{array}{c}\text { Std. } \\
\text { Deviation }\end{array}$ & $\begin{array}{c}\text { Std. } \\
\text { Error Mean }\end{array}$ \\
\hline $\begin{array}{l}\text { Percentage correct on } \\
\text { level of knowledge }\end{array}$ & Female & 902 & 82,3523 & 11,16853 & 0,37187 \\
\hline & Male & 627 & 83,3913 & 10,91232 & 0,43580 \\
\hline
\end{tabular}

The descriptive statistics for gender groups are depicted in Table 9 and indicate that $902(59 \%)$ respondents are female and 627 (41\%) are male.

TABLE 10

T-TEST: INDEPENDENT COMPARISON OF THE MEAN DIFFERENCE SCORES OF THE DIFFERENT GENDER GROUPS

\begin{tabular}{llllllll}
\hline Levene's Test for Equality of Variances & \multicolumn{5}{c}{$\begin{array}{c}\text { t-test for } \\
\text { Equality of Means }\end{array}$} \\
\hline & F & Sig. & t & df & $\begin{array}{l}\text { Sig. (2- } \\
\text { tailed) }\end{array}$ \\
\hline $\begin{array}{l}\text { Percentage correct on } \\
\text { level of knowledge }\end{array}$ & $\begin{array}{c}\text { Equal variances } \\
\text { assumed }\end{array}$ & 0,875 & 0,350 & $-1,806$ & 1527 & 0,071 \\
\hline
\end{tabular}

No statistically significant differences (Table 10) were found in the mean scores pertaining to the level of knowledge between the different gender groups $[\mathrm{t}(\mathrm{df}=1527)=-1,806, \mathrm{p}=0.071>$ $0,05]$. Based on Partial ETA Squared (Table 11 ) only $4.6 \%$ of the variance in level of knowledge can be attributed to differences in gender scores. Hence the observed differences between gender groups are neither of statistical significance nor of practical significance.

TABLE 11

Directional Measures

\begin{tabular}{lccc}
\hline & & Value \\
\hline Nominal by Interval & Eta & $\begin{array}{c}\text { Percentage correct on level } \\
\text { of knowledge Dependent }\end{array}$ & 0,046 \\
\hline
\end{tabular}

ETA

$0,1-0,3$ (Small effect)

$0,4-0,5$ (Moderate effect)

$>0,5$ (Large effect)

TABLE 12

DESCRIPTIVE STATISTICS ON AGE GROUPS

\begin{tabular}{lccccccccc}
\hline & & & \multicolumn{8}{c}{$\begin{array}{c}95 \% \text { Confidence } \\
\text { Interval for Mean } \\
\text { Lower } \\
\text { Bound }\end{array}$} & $\begin{array}{c}\text { Upper } \\
\text { Bound }\end{array}$ & $\begin{array}{c}\text { Mini- Maxi- } \\
\text { mum mum }\end{array}$ \\
\hline $\begin{array}{l}\text { 24 and } \\
\text { younger }\end{array}$ & 295 & 82,6502 & 11,66458 & 0,67914 & 81,3136 & 83,9868 & 31,82 & 100,00 \\
$25-29$ & 496 & 84,5308 & 9,44966 & 0,42430 & 83,6971 & 85,3644 & 31,82 & 100,00 \\
$30-39$ & 427 & 82,7656 & 10,75391 & 0,52042 & 81,7427 & 83,7885 & 40,91 & 100,00 \\
40 and & 313 & 79,9303 & 12,87195 & 0,72757 & 78,4987 & 81,3618 & 36,36 & 100,00 \\
$\begin{array}{l}\text { older } \\
\text { Total }\end{array}$ & 1531 & 82,7356 & 11,12108 & 0,28422 & 82,1781 & 83,2931 & 31,82 & 100,00 \\
\hline
\end{tabular}

The descriptive statistics for age groups are depicted in Table 12 and it is clear that that the majority of respondents fall in the age categories $25-29(32 \%)$ and $30-39(28 \%)$ years. The remainder of respondents were 24 years of age and younger (19\%) and 40 years of age and older (20\%).

TABLE 13

ANOVA: COMPARISONS OF LEVELS OF KNOWLEDGE IN RESPECT OF AGE GROUPS

\begin{tabular}{lcccccc}
\hline & $\begin{array}{c}\text { Sum of } \\
\text { Squares }\end{array}$ & df & $\begin{array}{c}\text { Mean } \\
\text { Square }\end{array}$ & F & Sig. & ETA \\
\hline Between Groups & 4064,230 & 3 & 1354,743 & 11,172 & 0,000 & 0,147 \\
Within Groups & 185163,763 & 1527 & 121,260 & & & \\
Total & 189227,993 & 1530 & & & & \\
\hline
\end{tabular}

ETA

$0,1-0,3$ (Small effect)

$0,4-0,5$ (Moderate effect)

$>0,5$ (Large effect)

Given the sample size, statistically significant differences (Table 13) were found in the mean scores of the different age groups (F 3; $1527=11,172$, p < 0,0005). However, based on Partial ETA Squared (Table 9) the effect of the level of age on knowledge is relatively small as ETA $=0,147<0,3$

\section{TABLE 14}

LEVENE'S TEST OF EQUALITY OF ERROR VARIANCES

\begin{tabular}{cccc}
\hline Levene Statistic & df1 & df2 & Sig. \\
\hline 8,392 & 3 & 1527 & 0,000 \\
\hline
\end{tabular}

The results of the Levene's test for equality of error variances are depicted in Table 14. As the null hypotheses of equal variances is rejected (see Table 14), the Dunnett T3 Post hoc tests are used to ascertain which of the age levels differ significantly.

TABLE 15

Post Hoc TeSTS: MultiPle COMPARISONS BETWEen AGE GROUPS

Percentage correct on level of knowledge

\begin{tabular}{lllcc}
\hline & \multicolumn{3}{c}{ Subset for alpha $=0,05$} \\
\hline & (Recoded) Age & N & 1 & 2 \\
\hline Scheffe (a,b) & 40 and older & 313 & 79,9303 & \\
& 24 and younger & 295 & & 82,6502 \\
& $30-39$ & 427 & & 82,7656 \\
& $25-29$ & 496 & & 84,5308 \\
& Sig. & & 1,000 & 0,150 \\
\hline
\end{tabular}

Means for groups in homogeneous subsets are displayed.

a) Uses Harmonic Mean Sample Size $=365,538$.

b) The group sizes are unequal. The harmonic mean of the group sizes is used. Type I error levels are not guaranteed.

The results of the Scheffe post hoc tests (for comparison between the different age groups) are depicted in Table 15. From Table 15 it is clear that the levels of knowledge of respondents in the age group 40 and older are significantly lower than that of respondents in the other age categories. However, it is important to note that, based on the Partial Eta Squared $(0,147)$, the effect of age on the level of knowledge is relatively small. $(0,147<0,3)$. See also Table 10 in this regard.

The descriptive statistics for respondents' perceived risk of becoming infected are depicted in Table 16. It is clear that the majority of respondents $(62 \%)$ do not believe that it is likely at 
all that they will become infected with HIV. $8 \%$ of respondents believe that they are somewhat likely and $2 \%$ believe that it is very likely that they will become infected with HIV. The remaining $27 \%$ of respondents are uncertain about their personal likelihood of becoming HIV-infected.

TABLE 16

Descriptive STATISTICS ON PERCEPTION OF CONTRACTING HIV

\begin{tabular}{|c|c|c|c|c|c|c|c|c|}
\hline & \multirow[b]{2}{*}{$\mathrm{N}$} & \multirow[b]{2}{*}{ Mean } & \multirow[b]{2}{*}{$\begin{array}{c}\text { Std. } \\
\text { Deviation }\end{array}$} & \multicolumn{3}{|c|}{$\begin{array}{l}\text { 95\% Confidence } \\
\text { Interval for Mean }\end{array}$} & \multirow[b]{2}{*}{$\begin{array}{l}\text { Mini- } \\
\text { mum }\end{array}$} & \multirow[b]{2}{*}{$\begin{array}{l}\text { Maxi } \\
\text { mum }\end{array}$} \\
\hline & & & & $\begin{array}{l}\text { Std. } \\
\text { Error }\end{array}$ & $\begin{array}{l}\text { Lower } \\
\text { Bound }\end{array}$ & $\begin{array}{l}\text { Upper } \\
\text { Bound }\end{array}$ & & \\
\hline $\begin{array}{l}\text { Not } \\
\text { likely } \\
\text { at all }\end{array}$ & 954 & 83,2762 & 10,47576 & 0,33917 & 82,6106 & 83,9418 & 31,82 & 100,00 \\
\hline $\begin{array}{l}\text { Some } \\
\text { what } \\
\text { likely }\end{array}$ & 125 & 85,5636 & 11,19470 & 1,00128 & 83,5818 & 87,5455 & 36,36 & 100,00 \\
\hline Uncertain & n 416 & 81,3265 & 11,90367 & 0,58363 & 80,1793 & 82,4737 & 36,36 & 100,00 \\
\hline $\begin{array}{l}\text { Very } \\
\text { likely }\end{array}$ & 34 & 76,3369 & 13,27715 & 2,27701 & 71,7043 & 80,9695 & 45,45 & 95,45 \\
\hline Total & 1529 & 82,7784 & 11,09924 & 0,28385 & 82,2216 & 83,3352 & 31,82 & 100,00 \\
\hline
\end{tabular}

TABLE 17

ANOVA: COMPARISONS OF LEVELS OF KNOWLEDGE IN RESPECT OF PERCEPTION OF CONTRACTING HIV

\begin{tabular}{lcccccc}
\hline & $\begin{array}{c}\text { Sum of } \\
\text { Squares }\end{array}$ & df & $\begin{array}{c}\text { Mean } \\
\text { Square }\end{array}$ & F & Sig. & ETA \\
\hline Between Groups & 3493,769 & 3 & 1164,590 & 9,613 & 0,000 & 0,136 \\
Within Groups & 184745,209 & 1525 & 121,144 & & & \\
Total & 188238,978 & 1528 & & & & \\
\hline
\end{tabular}

ETA

$0,1-0,3$ (Small effect)

$0,4-0,5$ (Moderate effect)

$>0,5$ (Large effect)

Given the sample size, statistically significant differences (Table 17) were found in the mean scores between levels of knowledge and perceived perception of contracting HIV/AIDS (F 3; $1525=9,613$, p < 0,0005). However, based on Partial ETA Squared (Table 13) the effect of level of knowledge on perception is relatively small as ETA = $0,136<0,3$.

TABLE 18

LEVENE'S TEST OF EQUALITY OF VARIANCES

\begin{tabular}{cccc}
\hline Levene Statistic & df1 & df2 & Sig. \\
\hline 2,854 & 3 & 1525 & 0,036
\end{tabular}

The results of the Levene's test for equality of error variances are depicted in Table 18. It is evident that the error variance for knowledge differences is unequal across groups $(p<0,05)$ and therefore the Dunnett is used to compare variances (Table 18).

The results of the post hoc tests are depicted in Table 19 which shows that there are significant differences in the mean level of knowledge between respondents who believe they know a great deal about HIV/AIDS and those who believe they have lower levels of knowledge. In particular, those who believe they know a great deal scored on average $86 \%$ for the knowledge test.

From Table 20 it is clear that level of knowledge correlates significantly negatively ( $p<0,0005$ ) with discriminatory practices (Pearson Correlation $=-0,287$ ). Due to the actual magnitude of the correlation we, however, conclude that the effect of level of knowledge on discriminatory practices is relatively small.

\section{TABLE 19}

Post Hoc Tests: MulTiPle COMPARISONS ON LEVELS OF KNOWLEDGE

\begin{tabular}{|c|c|c|c|c|c|c|c|}
\hline & $\begin{array}{l}\text { (I) } \\
\text { (Recoded) } \\
\text { Highest } \\
\text { educa- } \\
\text { tion level }\end{array}$ & $\begin{array}{l}(\mathrm{J}) \\
\text { (Recodec } \\
\text { Highest } \\
\text { educa- } \\
\text { tion level }\end{array}$ & $\begin{array}{c}\text { Mean } \\
\text { d) } \begin{array}{c}\text { Dif- } \\
\text { ference } \\
(I-J)\end{array}\end{array}$ & $\begin{array}{l}\text { Std. } \\
\text { Error }\end{array}$ & Sig. & $\begin{array}{l}\text { Lower } \\
\text { Bound }\end{array}$ & $\begin{array}{l}\text { Upper } \\
\text { Bound }\end{array}$ \\
\hline \multirow[t]{12}{*}{$\begin{array}{l}\text { Dunnett } \\
\text { T3 }\end{array}$} & $\begin{array}{l}\text { A great } \\
\text { deal }\end{array}$ & Enough & $4,5155\left(^{*}\right)$ & 0,75320 & 0,000 & 2,5205 & 6,5105 \\
\hline & & $\begin{array}{l}\text { Just a } \\
\text { little }\end{array}$ & $11,6527(*)$ & 0,93654 & 0,000 & 9,1792 & 14,1263 \\
\hline & & $\begin{array}{l}\text { Noth- } \\
\text { ing }\end{array}$ & $26,3409\left(^{*}\right)$ & 4,79511 & 0,002 & 10,7954 & 41,8864 \\
\hline & Enough & $\begin{array}{l}\text { A great } \\
\text { deal }\end{array}$ & $-4,5155\left(^{*}\right)$ & 0,75320 & 0,000 & $-6,5105$ & $-2,5205$ \\
\hline & & $\begin{array}{l}\text { Just a } \\
\text { little }\end{array}$ & $7,1373\left(^{*}\right)$ & 0,70684 & 0,000 & 5,2713 & 9,0032 \\
\hline & & $\begin{array}{l}\text { Noth- } \\
\text { ing }\end{array}$ & $21,8254\left(^{*}\right)$ & 4,75558 & 0,007 & 6,2964 & 37,3545 \\
\hline & $\begin{array}{l}\text { Just a } \\
\text { little }\end{array}$ & $\begin{array}{l}\text { A great } \\
\text { deal }\end{array}$ & $-11,6527\left(^{*}\right)$ & 0,93654 & 0,000 & $-14,1263$ & $-9,1792$ \\
\hline & & Enough & $-7,1373\left({ }^{*}\right)$ & 0,70684 & 0,000 & $-9,0032$ & $-5,2713$ \\
\hline & & $\begin{array}{l}\text { Noth- } \\
\text { ing }\end{array}$ & 14,6882 & 4,78804 & 0,066 & $-0,8541$ & 30,2304 \\
\hline & Nothing & $\begin{array}{l}\text { A great - } \\
\text { deal }\end{array}$ & $-26,3409\left(^{*}\right)$ & 4,79511 & 0,002 & $-41,8864$ & $-10,7954$ \\
\hline & & Enough & $-21,8254\left(^{*}\right)$ & 4,75558 & 0,007 & $-37,3545$ & $-6,2964$ \\
\hline & & $\begin{array}{l}\text { Just a } \\
\text { little }\end{array}$ & $-14,6882$ & 4,78804 & 0,066 & $-30,2304$ & 0,8541 \\
\hline
\end{tabular}

* The mean difference is significant at the 0,05 level.

TABLE 20

CORRELATIONS: KNOWLEDgE AND DISCRIMINATORY PRACTICES

\begin{tabular}{llcc}
\multicolumn{4}{c}{ Percentage correct on level of knowledge } \\
\hline $\begin{array}{l}\text { Pection } 4 \text { Factor }(2,3,4,5) \\
\text { on level of knowledge }\end{array}$ & Pearson Correlation & 1 & $-0,287\left({ }^{* *}\right)$ \\
& Sig. (2-tailed) & 0 & 0,000 \\
& N & 1532 & 1525 \\
Section 4 Factor & Pearson Correlation & $-0,287\left({ }^{* *}\right)$ & 1 \\
$(2,3,4,5)$ & Sig. (2-tailed) & 0,000 & 0 \\
& N & 1525 & 1525 \\
\hline
\end{tabular}

** Correlation is significant at the 0,01 level (2-tailed).

There is no significant correlation between knowledge and behaviour; (Pearson's Correlation $=0,012, p=0,679>0,05$ )

\section{DISCUSSION}

The main objective of this study was to determine if there is a relationship between increasing levels of knowledge about HIV/AIDS and perceptions of discriminatory attitudes and behaviour towards people with HIV/AIDS.

From the findings it is evident that respondents are generally knowledgeable about the transmission and prevention of HIV/AIDS. The results of this study indicate that respondents are 
knowledgeable about the four main methods of HIV transmission, namely through sexual contact, through transfusion of contaminated blood, through the sharing of contaminated needles among HIV drug users and from an infected mother to her baby during pregnancy. Results of the survey also suggest that the majority of respondents were clear that HIV cannot be transmitted through casual contact such as sharing of communal toilets, sharing of cutlery and crockery and sharing of tools and equipment. A greater uncertainty was expressed regarding whether HIV can be contracted via exposure to an infected person's bodily fluids such as saliva and whether mosquitoes could transmit the virus. Specifically, a total of $23 \%$ were not sure as to whether one can be infected with HIV after kissing an infected person. $24 \%$ did not know about the likelihood of transmission of HIV through mosquitoes, while $14 \%$ believed incorrectly that one could be exposed to HIV from mosquitoes. Although all scientific data available leads to the conclusion that HIV cannot be transmitted through these modes, respondents appear not be convinced of this fact, as the above findings suggest. Results of this study corroborate the findings of research conducted in the Far East (Lim et al., 1999).

Considering the last mentioned findings, it is not surprising to find that $46 \%$ of employees would not feel comfortable or are uncertain about whether they would be comfortable working with an infected colleague. Although employees showed a high level of knowledge and awareness that HIV can not be transmitted through the various means of casual contact, $43 \%$ were not willing to or uncertain about using the same toilets as an infected person, $46 \%$ were not comfortable or uncertain about sharing crockery and cutlery and 39\% were not comfortable or uncertain about sharing tools or equipment with an infected person. Although respondents indicated that they know that HIV cannot be transmitted through casual contact (as this is what they have been told) they may remain unconvinced of scientific findings because they worry that new evidence may come to light at a later date that points to the possibility of HIV transmission occurring through casual contact.

This study further highlighted that only $14 \%$ of employees believed that their colleagues would not avoid them if they found out that they had HIV or AIDS. The remaining $44 \%$ of respondents believe that they will be ostracised and $42 \%$ were uncertain about their colleagues' reactions should their HIV status become known. The last-mentioned finding substantiates findings of Barrows et al. (1996) and Lau and Wong (2001) that individuals believe that they will be discriminated against or that others will resist working alongside or avoid them if they were found to be HIV positive.

Despite the last mentioned scepticism and concern that respondents showed regarding the transmission of HIV by means of casual contact it is evident from the findings that, although the relationship between levels of knowledge about HIV/AIDS and discriminatory behaviour toward people with HIV/AIDS is relatively small, the level of knowledge correlates negatively with discriminatory practices. These findings corroborate the findings of research conducted by Chiliaoutakis et al. (1996). It would therefore appear that these results indicate that such respondents are able apply the data and information that they have received regarding HIV/AIDS in a meaningful manner which then results in non-discriminatory practices.

The study further assesses whether several comparison groups created in terms of the different biographical variables had differing scores with regard to level of knowledge. The results of this study indicated that there is a meaningful difference between the average levels of knowledge and respondents' education level and age. However, based on the effect size, the effect of level of education and age on knowledge is relatively small. This Survey's findings corroborate findings of Garbus (2002) in that no significant difference was found between the knowledge of men and women.
Findings of this study correspond to findings of De Bruyn (1998), Garbus (2002) and Norman et al. (2003) that AIDS knowledge is higher among people with more education and amongst younger people. In South Africa the lower knowledge of respondents 40 years and older can be ascribed to such employees having been less likely to have received sex education and HIV/AIDS education particularly in school in comparison to younger respondents. Linking findings back to earlier discussion regarding the formation of attitudes it could be argued that older respondents' meaning structures with regard to sex and sexually transmitted diseases may differ from those of younger respondents in that meaning structures were formed in the absence of exposure to HIV/AIDS. Older employees were thus required to fit the concept of HIV/AIDS (new information) into their already existing categories at a much later stage in their lives. According to Worchel et al. (1991) all new information is distorted to some degree in order to fit into already existing categories and existing categories have to expand to accommodate such information. Depending on a number of variables, including the extent to which the individual is set in his/her ways or willingness to change existing categories, accommodation of information regarding HIV/AIDS would or would not take place. In comparison, younger respondents formed their meaning structures inclusive of HIV/AIDS due to their exposure to HIV/AIDS from a much earlier age.

The same argument can be used for the findings that indicate that the higher the respondent's level of education the higher the level of knowledge. Respondents with a higher level of education may find it less difficult to assimilate and accommodate new information into existing concepts as this is primarily what training in any field teaches and requires an individual to do. It would therefore appear that both educational level and age may be contributing factors in the formation of different mental models.

Another interesting finding was that although no correlation was found between level of knowledge and behaviour that places one at risk of infection, a significant difference was found between level of knowledge and respondents' perceived risk of becoming infected (given the large sample size the impact thereof remains small). Respondents with high levels of knowledge perceived themselves to be at lower risk of infection and respondents with lower levels of knowledge perceived themselves as having a higher probability of becoming infected. The last mentioned findings correspond with Norman et al. (2003) findings that knowledge was associated with concern about personal risk of contracting AIDS. Findings may be attributed to respondents' (with a higher level of knowledge) understanding of the difference between putting themselves at risk for infection, thus having to make a pre-behavioral decision, and knowing when they are already at risk of being infected due to past decisions. Respondents with a higher level of knowledge are more likely to know that one increases one's risk of infection through high-risk practices such as having unprotected sex with a partner, having unprotected sex with sex workers who are at high risk of becoming infected themselves, by sharing needles/ syringes to inject drugs/ steroids or by having unprotected sex with individuals who have previously placed themselves at high risk of becoming infected. Results of the survey show that a concerning $8 \%$ of respondents (125 employees) believed that they were "somewhat" likely to become infected with HIV and that a further $2 \%$ of respondents ( 34 employees) believed that they were very likely of becoming infected. It would therefore appear that these respondents are evidently aware of their previous and current "risk" practices. The $27 \%$ of respondents who stated that they are uncertain about their personal likelihood of becoming infected with HIV may not understand/be knowledgeable about at-risk practices that place them at risk of HIV infection.

Despite the findings based on Partial ETA Squared that the effect of level of knowledge is relatively small, the findings of the research conducted still add value by means of determining the 
various knowledge levels. Education regarding HIV/AIDS will continue to be a key component in any strategy to reduce or prevent stigma and discrimination against people with HIV/AIDS as stigma and discrimination may result in isolation and marginalization, increased vulnerability to infection and increased likelihood of general health risks (De Bruyn, 1998). The Employment Equity Act specifically protects individuals from discrimination and it is therefore important to identify possible discriminatory attitudes and practices, which might hold Labour Relations implications for the organisation. Discriminatory behaviour not only affects the employer employee relationship but can also damage the public's view of the organisation which will have other far-reaching negative consequences. According to Firmansyah and Kleiner (1999) AIDS discrimination in the workplace is not limited to the employer employee relationship but can also take place between business and its customers. The last-mentioned can have a further devastating impact on the organisation's bottom line.

The implications of these findings can be summarised as follows:

1. The provision of HIV/AIDS educational intervention programs are imperative in reducing discriminatory attitudes and behaviour towards people infected with HIV/AIDS.

2. By reducing discriminatory attitudes and behaviour one contributes to a milieu of acceptance and understanding which in turn assists in reducing fear and denial and thereby indirectly reduces the risk of new infections.

3. Current thinking regarding "at risk" groups such as younger age groups, should be reconsidered, since such "stereotyping of risk" can contribute to older individuals not perceiving themselves to be at risk when they may in fact be at higher risk due to their lower level of knowledge and past lack of exposure to sex and HIV/AIDS education.

4. HIV/AIDS intervention programs should have the dual aim of providing information, according to Bellinger et al. (2004) information is data that has been given meaning by way of relational connection, this meaning can be useful, but does not have to be, and education (knowledge and understanding). People first need information i.e. the facts, which will help to lay the foundation for health education.

Shortcomings of the study are the following:

1. It is focused mainly on knowledge of transmission, few questions regarding knowledge of prevention e.g. effectiveness of latex condoms vs. natural membrane condoms, the effect of oil based lubricants on condoms etc.

2. Fear and denial were not a main focus of the survey

3. The sample group is not representative of the general South African population (high educational levels)

4. Findings may be limited to the specific organisation due to its specific environmental setting

5. Cannot ascribe high level of knowledge to educational and other interventions offered by the organisation only. Other sources of information e.g. mass media campaigns, community-based and interpersonal interventions, informal networks e.g. friends and family may also have played a role.

6. Although it has been noted that both knowledge and a supportive and caring environment is required to adequately reduce stigma and discrimination, this study focused only on the link between knowledge and attitude towards those infected, and disregarded the structural components.

\section{REFERENCES}

Aggleton, P., Whitty, G., Knight, A., Prayle, D., Warwick, I. \& Rivers, K. (1998). Promoting young people's health: concerns and needs of young people. Health Education, 98, (6), 213-219.

Arnold, J., Cooper, C. \& Robertson, I. (1995). Work Psychology: Understanding human behaviour in the workplace. London: Pitman Publishing.

Avert.Org. (2004). HIV \& AIDS stigma and discrimination: Attitudes towards HIV \& AIDS. Retrieved February 17, 2004 from http://www.avert.org/aidsstigma.html.
Barrows, C.W., Gallo, M. \& Mulleady, T. (1996). AIDS in the US hospitality industry: Recommendations for education and policy formulations. International

Journal of Contemporary Hospitality Management, 5, (1), 5 - 9.

Bhate, S. (1999). Cognitive style differences and their impact on responses to message sources. Marketing Intelligence and Planning, 17, (6), 280 - 287.

Chandra, P.S., Deepthivarm, A.S. \& Manjula, V. (2003). Disclosure of HIV infection in South India: Patterns, reasons and reactions. AIDS Care, 15, (2), $207-215$.

Corporate Leadership Council. (2002). Strategies for HIV/AIDS Management. Retrieved April 21, 2004 from http://www.corporateleadershipcouncil.com.

Connors, J. \& Heaven, P. (1995). Health beliefs and attitudes towards people living with HIV/AIDS. Journal of Applied Social Psychology, 25, (10), 922-931.

Cook, C.W. \& Hunsaker, P.L. (2001). Management and Organizational Behaviour. New York: McGraw-Hill.

Cox, S. \& Cox, T. (1991). Structure of employee attitudes to safety: A European example. Work and Stress, 48, (3), 93-106.

De Bruyn, T. (1998). HIV/AIDS and Discrimination: A discussion paper. Canadian HIV /AIDS Legal Network and Canadian AIDS Society, Montreal.

Dixon, N.M. (1999). The organizational learning cycle. USA:Gower.

Dougherty, D. Borelli, L., Munir, K., \& O'Sullivan, A. (2000). Systems of Organizational sense making for sustained product innovation. Journal of Engineering and Technology Management, 17, 321-355.

Ferris, G.R., Bhawuk, D., Fedor, D.F. \& Judge, T.A. (1995). Organizational politics and citizenship: Attributions of intentionality and construct definition, In Martinko, M.J., Attribution theory: an organizational perspective, (231-251). Delray Beach: St Lucie Press.

Firmansyah, S. \& Kleiner, B.H. (1999). New developments concerning discrimination against workers with HIV or AIDS. Equal Opportunities International, 18, 2 - 4 .

Garbus. L. (2002). UCSF: Country AIDS Policy Analysis Project. Regents of the University of California.

Goffman, E. (1963). Stigma: Notes on the Management of a spoiled identity. New York: Simon \& Schuster.

Grunseit, A.C. \& Aggleton, P. (1998). Lessons learned: An update on the published literature concerning the impact of HIV and sexuality education for young people. Health Education, $2,45-54$.

Hellriegel, D., Jackson, S.E. \& Slocum, J.W. (1999). Management. Cincinnati, Ohio: South-Western College Publishing.

HIVInSite. (2004). Center for HIV information. Retrieved March 31, 2004 from http://hivinsite.ucsf.edu/global? page $=$ cr09-sf-00

Holton, E.F. \& Baldwin, T.T. (2000). Making transfer happen: an action perspective on learning transfer systems. Advances in Developing Human Resources, 8, 1-6.

Horizons. (2004). HIV/AIDS related stigma, pp.13 - 15. Retrieved February 17, 2004 from http://www.popcouncil.org/ horizons.html.

Human Sciences Research Council of South Africa. (2002). Research programmes: Social aspects of HIV/AIDS and health (saha). Retrieved March 23, 2004 from http://www.src.ac.za/ research/npa/SAHA/news/news20021205.html.

Ivancevich, J.M. \& Matteson, M.T. (1996). Organizational Behaviour and Management. USA: Irwin.

Jourdan, J., \& Etkind, P. (2004) Enhancing HIV/AIDS and STD prevention through program integration. Public Health Reports, 119, (1), 4-11.

Lau, J.T.F., Tsui, H.Y., Li, C.K., Chung, R.W.Y., Chan, M.W., \& Molassiotis, A. (2003). Needs assessment and social environment of people living with HIV/AIDS in Hong Kong. AIDS Care, 15, (5), 699 - 706.

Lau, J.T.F \& Wong, W.S. (2001). AIDS related discrimination in the workplace - the results of two evaluative surveys carried out during a three year period in Hong Kong. AIDS Care, 13, (4), 433 - 440. 
Lewis, M.H. (1990). An Investigation to predict the extend of discrimination based upon the existence of stereotypes and prejudicial attitudes against woman in managerial positions. For partial fulfillment of the requirements for the degree "Master of Personnel Guidance". University of the Orange Free State, Bloemfontein.

Lim, V.K.G \& Loo, G.L (1999). HIV and the workplace. Organisational consequences of hiring persons with HIV and attitudes towards disclosure of HIV related information. International Journal of Manpower. 21, (2), 129 - 140.

Martinko, M.J. (1995). The nature and function of attribution theory within the organizational sciences. In Martinko, M.J. Attribution theory: an organizational perspective. (7-14). Delray Beach: St Lucie Press.

Norman, L.R. \& Carr, R. (2003). The role of HIV knowledge on HIV related behaviors: A hierarchical analysis of adults in Trinidad. Health Education, 103, (3), 145 - 155.

Pangaea Global AIDS Foundation. (2004). South African HIV/AIDS Statistics. Retrieved March 31, 2004 from: http://www.pgaf.org/pressreleases//south_africa_stats.html.

Parker, R. \& Aggleton, P. (2002). HIV/AIDS-related stigma and discrimination: A conceptual framework and an agenda for action. Horizons Program and Population Council.

Quah, S.R. (1998). Ethnicity, HIV/AIDS Prevention and Public Health Education. International Journal of Sociology and Social Policy, 18, 7- 8.

Ragan, A.M \& Bowen, A.M. (2001). Improving attitudes regarding the elderly population: The effects of information and reinforcement for change. The Gerontologist, 41, (4), 511 -515.

Schalk, R., Cambell, J.W. \& Freese, C. (1998). Change and employee behaviour. Leadership and Organization Development Journal, 19, 157-163.

Sixsmith, J., Kelleher, C.C. \& Crangle, E. (2000). Impact evaluation of an HIV screen educational advertisement. Health Education, 100, (1), 42-49.

Thomas, H. \& Pollock, T. (1999). From I-O economics' S-C-P paradigm through strategic groups to competence-based competition: reflections on the puzzle of competitive strategy. British Journal of Management, 10, 127-140.

UNAIDS. (2000). Report on the global HIV/AIDS epidemic 2002. Retrieved January 8, 2003 from: http://www.unaids.org/ barcelona/presskit/barcelona\%20report/chapter3.html.

UNAIDS. (2003). Fact Sheet: Stigma and discrimination. Retrieved February 17, 2004 from http://www.unaids.org.

Veldsman, T.H. (1998). Exploring the living organization: the concept organizational culture. In J.A. Slabbert; J.J. Prinsloo; B.J. Swanepoel; W. Backer (Eds). Managing Employment Relations in South Africa, (8-1-18-25). Durban: LexisNexis Butterworths.

Weber, P.S. \& Weber, J.E. (2001). Changes in employee perceptions during organizational change. Leadership and Organization Development Journal, 22, 291-300.

Weick, K.E. (1995). Sense making in organizations. London: Sage.

Worchel, S., Cooper, J. \& Goethals, G.R. (1991). Understanding social psychology. New York: Wadsworth, Inc. 